\title{
Evaluation of the economic viability of grid-connected photovoltaic systems in different Brazilian regions
}

\author{
A valiação da viabilidade econômica de sistemas fotovoltaicos conectados à redle em diferentes \\ regiões do Brasil \\ Evaluación de la viabilidad económica de los sistemas fotovoltaicos conectados a la red en \\ diferentes regiones del Brasil
}

Received: 12/09/2021 | Reviewed: 12/15/2021 |Accept: 12/17/2021| Published: 12/24/2021

\author{
Adrielle Cristina Ozanski \\ ORCID: https://orcid.org/0000-0002-2970-8956 \\ Universidade Estadual do Oeste do Paraná, Brasil \\ E-mail: a.ozanski@hotmail.com \\ Maurício Ivan Cruz \\ ORCID: https://orcid.org/0000-0003-2912-3189 \\ Universidade Estadual do Oeste do Paraná, Brasil \\ E-mail: mauricioivancruz@gmail.com \\ Jair Antonio Cruz Siqueira \\ ORCID: https://orcid.org/0000-0002-8140-444X \\ Universidade Estadual do Oeste do Paraná, Brasil \\ E-mail: jair.siqueira@unioeste.br \\ Thaís Caroline Gazola \\ ORCID: https://orcid.org/0000-0001-8947-0372 \\ Universidade Estadual do Oeste do Paraná, Brasil \\ E-mail: thais_caroline_gazola@ hotmail.com \\ Renata Galvan Rutz da Silva \\ ORCID: https://orcid.org/0000-0003-0207-2182 \\ Universidade Estadual do Oeste do Paraná, Brasil \\ E-mail: arq.renatagalvan@ hotmail.com \\ Luciene Kazue Tokura \\ ORCID: https://orcid.org/0000-0001-9758-0141 \\ Universidade Estadual do Oeste do Paraná, Brasil \\ E-mail: lucienetokura@gmail.com \\ Carlos Eduardo Camargo Nogueira \\ ORCID: https://orcid.org/0000-0003-3886-9118 \\ Universidade Estadual do Oeste do Paraná, Brasil \\ E-mail: cecn1@yahoo.com.br
}

\begin{abstract}
This study aimed at the dimensioning and economic analysis of grid-connected photovoltaic systems in different cities in Brazil. As a criterion for the selection of the cities of interest, it was considered the capital with the highest number of residences in each of the five regions of the country, as well as the city where the authors are established, namely the cities of Salvador, Manaus, Goiânia, São Paulo, Curitiba, and Cascavel. Based on local characteristics and adopting an average monthly electricity consumption of $400 \mathrm{kWh}$, was developed the dimensioning of the photovoltaic systems, adopting the methodology presented by Pinho and Galdino (2014). Based on the components determined for the systems, budgets were made to enable their implementation. The investments to be made varied between US\$ 4,682.97 and US\$ 5,326.06. From these values, economic analyses were made using the discounted payback method. The projects presented different payback times, with the shortest payback time to the city of Manaus, with 9 years and the longest in the city of Curitiba, with 15 years. Therefore, it was confirmed the research hypothesis that the regional characteristics linked to the dimensioning of the photovoltaic systems directly affect the time of return on investment.
\end{abstract}

Keywords: Solar energy; Dimensioning; Economic analysis.

\section{Resumo}

Este estudo teve como objetivo o dimensionamento e a análise econômica de sistemas fotovoltaicos conectados à rede em diferentes cidades do Brasil. Como critério para a seleção dos municípios de interesse, foi considerada a capital com maior número de residências em cada uma das cinco regiões do país, bem como, a cidade onde os autores estão estabelecidos, ou seja, as cidades de Salvador, Manaus, Goiânia, São Paulo, Curitiba e Cascavel. Com base nas 
características locais e adotando um consumo médio mensal de eletricidade de $400 \mathrm{kWh}$, foi desenvolvido o dimensionamento dos sistemas fotovoltaicos, adotando-se a metodologia apresentada por Pinho e Galdino (2014). Com base nas componentes determinadas para os sistemas, os orçamentos foram realizados para permitir a sua implementação. Os investimentos a serem realizados variaram entre U\$ 4.682,97 e US\$ 5.326,06. A partir desses valores, as análises econômicas foram conduzidas pelo método de retorno descontado. Os projetos apresentaram diferentes tempos de retorno, com o menor tempo de retorno para a cidade de Manaus, com 9 anos e o maior da cidade de Curitiba, com 15 anos. Portanto, foi confirmada a hipótese de pesquisa de que as características regionais ligadas ao dimensionamento dos sistemas fotovoltaicos afetam diretamente o tempo de retorno do investimento.

Palavras-chave: Energia solar; Dimensionamento; Análise econômica.

\section{Resumen}

Este estudio tuvo como objetivo el dimensionamiento y el análisis económico de sistemas fotovoltaicos conectados a la red en diferentes ciudades de Brasil. Como criterio para la selección de los municipios de interés, fue considerada la capital con mayor número de residencias en cada una de las cinco regiones del país, así como, la ciudad donde los autores están establecidos, o sea, las ciudades de Salvador, Manaus, Goiânia, São Paulo, Curitiba y Cascavel. Con base en las características locales y adoptando un consumo medio mensual de electricidad de 400 kWh, se desarrolló el dimensionamiento de los sistemas fotovoltaicos, adoptando la metodología presentada por Pinho y Galdino (2014). Sobre la base de los componentes determinados para los sistemas, los presupuestos se realizaron para permitir su implementación. Las inversiones a realizar oscilaron entre U\$ 4.682,97 y US\$ 5.326,06. A partir de esos valores, los análisis económicos fueron conducidos por el método de retorno descontado. Los proyectos presentaron diferentes tiempos de retorno, con el menor tiempo de retorno para la ciudad de Manaus, con 9 años y el mayor de la ciudad de Curitiba, con 15 años. Por lo tanto, se confirmó la hipótesis de investigación de que las características regionales ligadas al dimensionamiento de los sistemas fotovoltaicos afectan directamente el tiempo de retorno de la inversión.

Palabras clave: Energía solar; Dimensionamiento; Análisis económico.

\section{Introduction}

The oil crisis of the 1970s changed the way people evaluated the availability of natural resources around them. There was, worldwide, a strong incentive to search for new energy sources, mainly renewable, aiming to replace fossil fuels and nonrenewable means of energy (Nakabayashi, 2014).

Due to the irrational use of natural resources, not only the oil crisis, but a severe water crisis has affected many countries. Many nations are already experiencing a water crisis, which is set to worsen in the coming years as these countries develop (Cirilo, 2015; Silveira et al., 2021).

In Brazil, hydroelectric plants have the largest share in the production of electricity. Therefore, due to the water crisis, government agencies have created several incentives for the implementation and application of other energy sources, such as wind, biomass and solar, which have increased over the past few years (Nascimento, 2018; EPE, 2019; Maimoni \& Cardoso, 2020).

Among the energy sources, solar energy has become an important source of energy renewable. Photovoltaic solar systems have provided the use of this energy and their use has intensified in recent years. Estimates show that solar energy in the year 2018, reached the 584 TWh generation, this means a growth of 28,9\% worldwide. Brazil is still developing in this area. In 2018, 3.10 TWh were produced, representing a growth of $277.10 \%$ (BP, 2018).

Photovoltaic micro and mini generation have been an alternative that has been on the rise in recent years. It is a form of clean energy that uses solar radiation. It is easy to apply, in any land and place, and can be used by users connected or not to the power grid. Such projects have a direct contribution to the maintenance of sustainability and energy savings (Chamma, 2017; França, Vinagre, Fonseca, Lopes, Ponte \& Lima, 2021; Vargas, Siqueira, Tokura, Santos \& Feiber, 2021).

Since, the systems are organized and designed to meet a specific application, they can be used as an isolated system or as an installation connected to the network. Isolated systems are usually used in areas where there is no power grid, that is, in remote areas meeting the needs of simple household appliances, up to the power of an entire building. In the systems 
connected to the grid, the energy produced is injected directly into the public electricity grid, there is no storage of the electricity generated (Mundo-Hernández, Alonso, Hernández-Álvarez \& Celis, 2014).

In order to assess the viability of such an investment, it is necessary to define the cost of the electricity generated by the PV system and the overall financial performance of the project, considering its cash flows of both expenditure and revenue (Mitscher \& Rüther, 2012).

Given the above, this research aimed to dimension and compare the time of return on investment for photovoltaic microgeneration projects in different regions of Brazil, starting from the problem: Do the regional characteristics, linked to the dimensioning photovoltaic systems, impact the economic viability?

We aim to confront the hypothesis that the characteristics inherent to each region of Brazil directly affect the dimensioning and time of return on investments in similar photovoltaic microgeneration projects.

\subsection{Solar energy}

The Sun is the central star of our solar system and is located approximately $1.5 \times 10^{8} \mathrm{~km}$ from Earth. Every day it radiates an enormous amount of energy, from which the Earth receives only a small fraction, equivalent to $1.7 \times 10^{14} \mathrm{~kW}$. It is estimated that only 84 minutes of solar radiation on the Earth's surface meet the entire world's energy demand for one year (Kalogirou, 2014).

Solar energy is the most abundant form of energy on planet Earth. It comes from the Sun, generated by nuclear fusion, where hydrogen particles are converted into helium, releasing radiant energy in the form of light and heat. This energy can be used in different ways and by different systems, both natural as is the case of photosynthesis, as well as artificial ones such as thermosolar and photovoltaic (Nakabayashi, 2014).

It is important to note that solar radiation, which reaches the earth's surface, consists of two components, one direct and the other diffuse. The direct radiation is the one that produces clear shadows since it comes directly from the direction of the Sun. The diffuse component, on the other hand, has its origin in several directions, and before reaching the surface it suffers scattering through the terrestrial atmosphere. At least $20 \%$ of the radiation that reaches the globe is diffuse, even in days with total absence of clouds, however in completely cloudy days, there is no contribution of direct radiation. The technologies employed in photovoltaic panels allow the use of both direct and diffuse solar components (Pinho \& Galdino, 2014).

\subsubsection{Sun-Earth geometry}

The planet Earth rotates around the Sun, developing an elliptical orbit and has an inclination of its axis of approximately 23.5 degrees in relation to the normal plane of the ellipse. These factors result in seasonal variations in different latitudes of the globe. The most accentuated variations occur near the poles, and to a lesser extent, near the equator. These characteristics influence the seasons of the year (Bhatia, 2014).

Among the seasonal effects, we highlight the summer and winter solstices and the spring and autumn equinoxes. These events have different effects during the year for the duration of days and nights. During the solstices, the days have different durations. The winter solstice is characterized by shorter days, while the summer solstice is characterized by long days. During the equinoxes, the days and nights have the same duration because the Earth is lit equally in both hemispheres (Chamma, 2017). Figure 1 shows the Sun-Earth geometry. 
Figure 1. Sun-Earth Geometry.

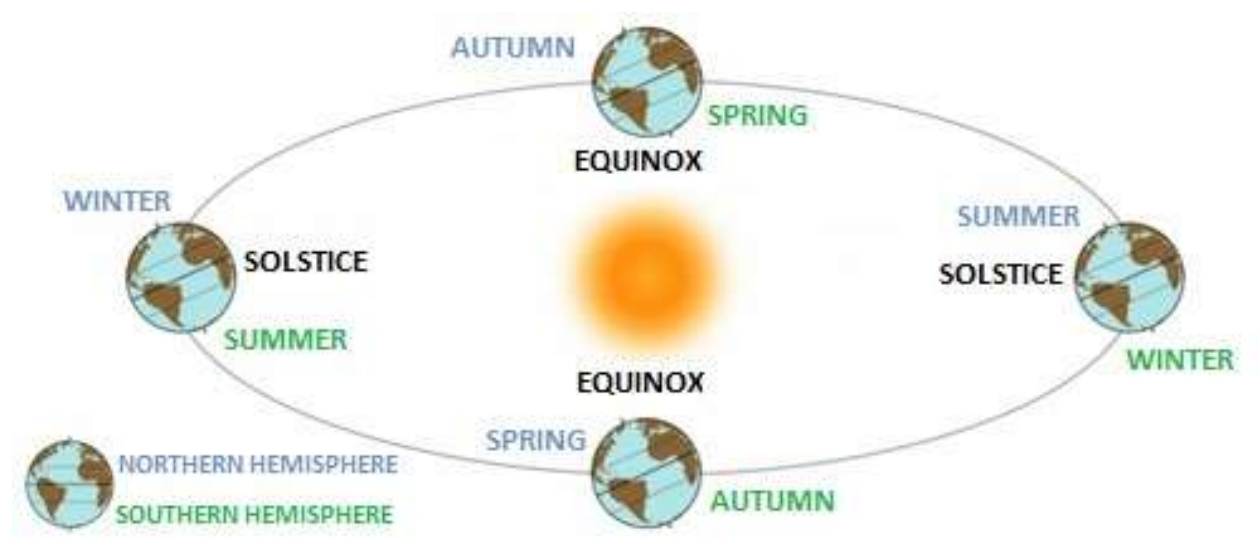

Source: Pereira et al. (2017). Adapted by the authors.

\subsubsection{Natural and artificial systems}

Within natural systems, solar energy is involved, even indirectly, as is the case with other energy matrices. Wind energy, for example, depends on the heat from the sun to heat the air masses. Biomasses depend on light and heat for biological growth processes. Energy from hydropower depends on the sun for the water cycle to occur constantly, ensuring that the process becomes cyclical (Pazuch, 2017; Pereira et al., 2017).

When it comes to artificial systems, thermosolar use the heat coming from the sun for different purposes. The most common application of this system is for the heating of water and in the projection of environments for use and maintenance of thermal comfort in buildings. On the other hand, sunlight is used by photovoltaic systems to generate electricity (Guney, 2016).

\subsection{Photovoltaic systems}

\subsubsection{Photovoltaic effect}

The conversion of solar energy into electricity is the essential property of a photovoltaic panel. It occurs mainly by capturing sunlight by a semiconductor material capable of generating potential differences and conducting electrons through the structure of the material, generating electric current (Xu, Wang, Zhou, Li \& Xu, 2018).

The photovoltaic effect is characterized as a complex quantum mechanism, which involves the absorption of photons, the migration of charge carriers through the material, and the generation of energy across the full extent of the crystalline microstructure inherent in each solar cell (Wen \& Zhou, 2019).

Photovoltaic systems are responsible for the conversion of sunlight incident on the surface of the planet Earth into an electrical voltage. This transformation occurs through the photovoltaic effect on photovoltaic panels, due to the presence of semiconductor materials such as silicon and selenium (Goh, 2019).

\subsubsection{Solar cell}

The solar cell is the most basic unit of the photovoltaic system. They are responsible for converting solar energy into electrical energy. The solar cells are connected in a series arrangement, and these series are connected in parallel to form a photovoltaic module, which is the basis of photovoltaic systems (Alves, 2016).

When sunlight falls on the photovoltaic cell, the energy excites the free electrons in the silicon atoms, causing them to run through the semiconductor material. This generates electricity in the form of direct current that travels through the installation and passes through a current inverter, transforming the direct current (CC) from the plates into alternating current 
(CA). In this way, the electrical energy can be used by the installations of residences and other places where the system is installed. This type of generation can be connected to the electrical grid or isolated with the use of batteries (Guney, 2016).

There are three main types of semiconductors used in solar cells. They are differentiated according to the atomic structure and are divided into monocrystalline, polycrystalline, and amorphous. Monocrystalline silicon has an orderly atomic structure, with higher energy conversion efficiency and, due to this, with higher manufacturing cost. Polycrystalline silicon has a less orderly atomic structure, resulting in lower efficiency and lower manufacturing cost when compared to monocrystalline. Amorphous is the cheapest semiconductor to manufacture; however, it possesses weak atomic structures and the lowest efficiency among the three types (Balfour, Shaw \& Nash, 2016).

\subsubsection{Elements of a photovoltaic system}

Besides the photovoltaic modules, a photovoltaic system is composed of several other constituent elements. Of these, elements of extreme relevance for the adequate functionality of the system, such as the Inverter and the String Box stand out.

Inverter and the equipment responsible for the conversion of the direct current, coming from the Photovoltaic modules, into alternating current, to be used by the enterprise where the system is installed. The appropriate inverter must be chosen for each type of system according to its dimensioning and the demand required by the system (Lacchini, 2017).

The connection of several photovoltaic modules the series is called a string. The set of strings can be connected via a string box. It concentrates the electrical wiring to subdivide it into two buses, positive and negative, in order to protect them from overloads and reverse currents (Villalva, 2015).

\subsection{Photovoltaic microgeneration}

\subsubsection{ANEEL resolution}

The National Electric Energy Agency, through regulations №. 482/2012 and 687/2015, established conditions for access to microgeneration and distributed mini generation, to reduce barriers to the connection of small renewable energy plants to distribution networks. The limits of the facilities were defined, and the distributed microgeneration corresponds to an electricity generation plant with an installed capacity of less than or equal to $75 \mathrm{~kW}$, and the distributed mini generation represents a unit of installed power greater than $75 \mathrm{~kW}$ and less than $5 \mathrm{MW}$ (ANEEL, 2012, 2015).

The electric power compensation system was also instituted, which consumers, being duly connected to a distribution network, can inject into that network the surplus electric power for later use, with a period of up to 60 months to use these credits (ANEEL, 2015).

\subsubsection{On-Grid Systems}

The systems are designed to meet specific situations. They can be used in areas where there is no service by power utilities, characterizing the system as independent or autonomous, which can meet the simple needs of domestic appliances, even whole buildings (Mundo-Hernández et al., 2014).

On the other hand, the systems connected to the network, also called on-grid or grid-tie, are characterized by being installed in places where there is the service of the electric power network and have a dual bias, sometimes using energy made available by the network, sometimes injecting into it the surplus production of energy. The goal of such systems is to generate energy in order to reduce the consumption of the public network as well as generate surplus energy. Thus, there is a reduction in costs with infrastructure for energy transmission, reduction of carbon emissions, and better use of empty areas and roofs (Villalva, 2015). 


\section{Methodology}

The experiment was developed in the city of Cascavel, in the Energy Laboratory - LENE, of the Western Paraná State University. The objects of study were the capitals with the highest number of households in each of the five regions of Brazil: in the northern region, the city of Manaus - AM; in the northeastern region, the city of Salvador - BA; in the central-western region, the city of Goiânia - GO; in the southeastern region, the city of São Paulo - SP and in the southern region, the city of Curitiba - PR and the city of Cascavel - PR. The data used to select the capitals were taken from the surveys of the Brazilian Institute of Geography and Statistics - IBGE (IBGE, 2018). Table 1 below shows the geographic coordinates for each of the cities of interest of the student.

Table 1. Geographical coordinates of the study cities.

\begin{tabular}{ccccc}
\hline Region & State & City & Latitude & Longitude \\
\hline North & Amazonas & Manaus & $03^{\circ} 07^{\prime} 58^{\prime \prime ~ S}$ & $59^{\circ} 59^{\prime} 11^{\prime \prime} \mathrm{W}$ \\
Northeast & Bahia & Salvador & $12^{\circ} 58^{\prime} 56^{\prime \prime} \mathrm{S}$ & $38^{\circ} 28^{\prime} 53^{\prime \prime} \mathrm{W}$ \\
Midwest & Goiás & Goiânia & $16^{\circ} 40^{\prime} 51^{\prime \prime} \mathrm{S}$ & $49^{\circ} 15^{\prime} 12^{\prime \prime} \mathrm{W}$ \\
Southeast & São Paulo & São Paulo & $23^{\circ} 33^{\prime} 03^{\prime \prime} \mathrm{S}$ & $46^{\circ} 38^{\prime} 00^{\prime \prime} \mathrm{W}$ \\
South & Paraná & Curitiba & $25^{\circ} 25^{\prime} 47^{\prime \prime} \mathrm{S}$ & $49^{\circ} 16^{\prime} 16^{\prime \prime} \mathrm{W}$ \\
South & Paraná & Cascavel & $24^{\circ} 57^{\prime} 42^{\prime \prime} \mathrm{S}$ & $53^{\circ} 26^{\prime} 10^{\prime \prime} \mathrm{W}$ \\
\hline
\end{tabular}

Source: Global Solar Atlas (2019). Adapted by the authors.

The dimensioning photovoltaic systems followed the methodology proposed by Pinho and Galdino (2014), which will be detailed next. The first steps of the dimensioning consist of the choice of location and the survey of the characteristics and solar resources available. Initially, it was necessary to establish the average monthly electricity consumption of the houses in each region. The Empresa de Pesquisa Energética - EPE (2018, 2019) provides the monthly average consumption data by region of Brazil for the year 2018. From these data, the average annual consumption was calculated for each region and, using the data referring to the housing from the IBGE (2018), it was possible to calculate the average annual consumption of electricity by housing, for each region in the year 2018, as presented in Table 2 below.

Table 2. Average annual electricity consumption per household for each region of Brazil.

\begin{tabular}{cccc}
\hline Region & Consumption $\left(\mathbf{k W h}\right.$ year $\left.{ }^{-\mathbf{1}}\right)$ & Number of residences & Average consumption (kWh res $\left.\mathbf{~ m o n t h}^{\mathbf{- 1}}\right)$ \\
\hline North & 780.764 .000 & 5.272 .000 & 148,10 \\
Northeast & 2.313 .000 .000 & 18.483 .000 & 125,14 \\
Midwest & 984.353 .000 & 5.496 .000 & 179,10 \\
Southeast & 5.564 .467 .000 & 31.023 .000 & 179,37 \\
South & 1.825 .327 .000 & 10.742 .000 & 169,92 \\
\hline
\end{tabular}

Source: EPE (2018, 2019) e IBGE (2018). Adapted by the authors.

From the calculated values, it was verified that the average annual consumption of each region presents little variation and low consumption, which makes it economically unfeasible for energy microgeneration projects. 
In order to stratify the proposed study, a fixed consumption value was then established in all regions, used to simulate the average consumption of a household, in which there is interest in applying a photovoltaic system. An average value of 400 $\mathrm{kWh} /$ month was set from the supply of two-phase residences, where they have a cost of the availability of the electrical system, in the value in local currency equivalent to $50 \mathrm{kWh}$ (ANEEL, 2018). Thus, the system will be dimensioned for the generation of $350 \mathrm{kWh} /$ month.

Then, the power of the microgenerator that makes up the photovoltaic system connected to the grid - SFCR; was calculated using the equation 1.

$$
P_{F V}=\frac{\left(\frac{E}{T D}\right)}{H S P_{M A}}
$$

Where:

$P_{F V}(\mathrm{kWp})=$ Total power of the photovoltaic panel;

$\mathrm{E}(\mathrm{kWh} / \mathrm{day})=$ Average annual daily consumption of the building or fraction;

TD (dimensionless) $=$ Performance rate;

$H S P_{M A}(\mathrm{~h} /$ day $)=$ Annual daily average of incident Full Sun Hours (HSP) in the photovoltaic panel plan.

The authors recommend values between 70 and $80 \%$ for TD, considering the solar radiation conditions found in Brazil, for residential SFCRs and conditions of good ventilation and not shaded.

The number of Full Sun Hours - HSP is the representation of the number of hours in which the solar irradiance remains constant and equal to $1 \mathrm{~kW} / \mathrm{m}^{2}$, so that the energy made available by the Sun, in the place in question, is corresponding to the resulting energy.

Based on the total power of the photovoltaic panel and the nominal power of the photovoltaic module, it was possible to calculate the number of modules required for the photovoltaic system using equation 2.

$$
N M=\frac{\left(P_{F V X 1000)}\right.}{P_{N M F}}
$$

Where:

NM (unit) = Number of photovoltaic modules;

$P_{F V}(\mathrm{kWp})=$ Total power of the photovoltaic panel;

PNMF $(\mathrm{Wp})=$ Nominal power of the photovoltaic module.

Then, the inverter dimensioning factor - FDI was calculated, obtained through equation 3, which is represented by the relationship between the nominal power of the inverter and the peak power of the photovoltaic generator.

$$
F D I=\frac{P_{N C A}}{P_{F V}}
$$

Where:

FDI (dimensionless) = Inverter dimensioning factor; 
$P_{F V}(\mathrm{kWp})=$ Total power of the photovoltaic panel;

$\operatorname{PINV}(\mathrm{Wp})=$ Nominal power of the inverter

The inverter input voltage, which is given by the sum of the associated module voltages in series, must also be considered. In this way, the authors warn of the caution that should be taken in calculating maximum voltage, because due to the risks of damaging the equipment, it must never be exceeded. Equation 4 can be used to calculate the maximum number of modules in series, called strings, respecting the maximum allowable voltage.

\section{NMFS x TOC $<$ TEMINV}

\section{Where:}

NMFS (unit) $=$ Number of photovoltaic modules in series;

TOC $(\mathrm{V})=$ Open circuit voltage of the photovoltaic module;

TEMINV (V) = Maximum inverter input voltage

Besides, the maximum number of strings connected in parallel was calculated so that it meets the maximum input current of the inverter (direct current - DC), using equation 5.

$$
\text { NFSP = IMEINV/ICCMF }
$$

Where:

NFSP $($ unit $)=$ Number of rows of photovoltaic modules in series connected in parallel;

$\operatorname{IMEINV}(\mathrm{A})=$ Maximum input current of the inverter;

$\operatorname{ICCMF}(\mathrm{A})=$ Short circuit current of the photovoltaic module .

The following components were chosen to compose the photovoltaic systems:

a) Photovoltaic module: $330 \mathrm{Wp}$ power, model BYD PHK-36-SERIES-4BB (according to the technical characteristics presented in Table 3).

Table 3. BYD photovoltaic module characteristics.

\begin{tabular}{lc}
\hline \multicolumn{1}{c}{ Item } & Module BYD 330 HK-36 \\
\hline Open Circuit Voltage (Voc) & $45.19 \mathrm{~V}$ \\
Maximum Operating Voltage (Vmp) & $37.83 \mathrm{~V}$ \\
Short Circuit Current (Isc) & $9.20 \mathrm{~A}$ \\
Maximum Operating Current (Imp) & $8.72 \mathrm{~A}$ \\
Maximum Power in STC (Pmax) & $330 \mathrm{Wp}$ \\
Module Efficiency & $16.70 \%$ \\
\hline
\end{tabular}

Source: BYD (2018). Adapted by the authors.

b) Solar Inverter: Ecosolys ECOS 2000 PLUS Grid-Tie Inverter, with $2000 \mathrm{~W}$ nominal power at the output and single-phase connection at $220 \mathrm{Vac}$.

Initially, a $4 \mathrm{kWp}$ inverter was selected; however, due to the maximum power voltage (Vmp) of each project, we noticed that despite meeting the expectations of maximum operating voltage, a single inverter could not meet the demand for open-circuit voltage (Voc). Because of these circumstances, we decided to use two $2 \mathrm{kWp}$ inverters for each project. The 
scheme presented in Figure 2 represents the arrangement of the photovoltaic modules for the system with 10 modules and is analogous to the systems of 11 and 12 modules.

Figure 2. Photovoltaic modules arrangement.

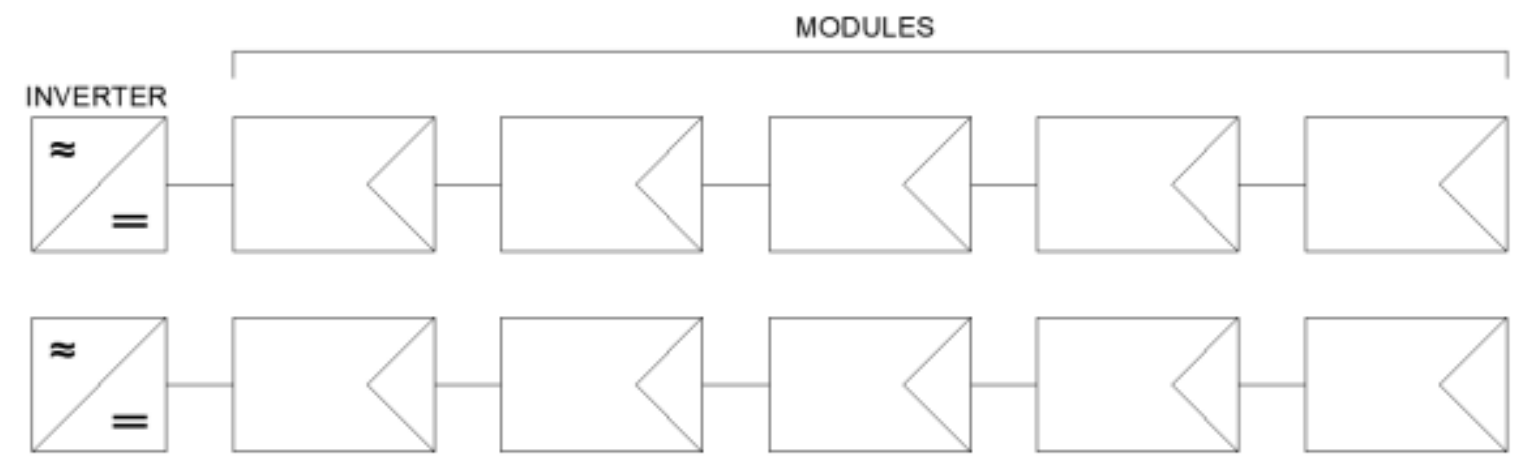

Source: Authors.

The technical specifications of the inverter are presented in Table 4.

Table 4. Ecosolys ECOS 2000 PLUS solar inverter data sheet.

\begin{tabular}{lc}
\hline \multicolumn{1}{c}{ Item } & Canadian CSI-5K-MTL \\
\hline DC INPUT & $2000 \mathrm{~W}$ \\
\hline Max. PV Power & $48 \mathrm{~V}$ \\
Start-up DC Input Voltage/Power & $480 \mathrm{~V}$ \\
Max. DC Input Voltage & $11,5 \mathrm{~A}$ \\
Max. Input Current (Isc) & $180 \sim 480 \mathrm{~V}$ \\
Operating DC Input Voltage Range & $189 \sim 480 \mathrm{~V}$ \\
MPPT Voltage Range & 1 \\
Number of MPP Trackers & MC4 Compatible \\
DC Inputs & $2000 \mathrm{~W}$ \\
\hline AC OUTPUT & $2200 \mathrm{~W}$ \\
\hline Rated AC Output Power & $220 \mathrm{~V}$ \\
Max. AC Output Power & $9,0 \mathrm{~A}$ \\
Nominal AC Output Voltage & $60 \mathrm{~Hz}$ \\
Nominal AC Output Current & $96,6 \%$ \\
Rated Output Frequency & Transformer less \\
Max. Efficiency & \\
AC Operating Range & Monophasic/Biphasic \\
AC Inputs & $99,5 \%$ \\
MPPT Efficiency & \\
\hline GENERAL DATA & $57,5 \sim 62,0 \mathrm{~Hz} / 176242 \mathrm{Vca}$ \\
\hline Operating Temperature Range & \\
Topology & \\
\hline & \\
\hline
\end{tabular}

Source: Ecosolys (2017). Adapted by the authors. 
c) String Box: brand Proauto, model SB-1E/2E-1S-1000V

Table 5. String box Proauto characteristics.

\begin{tabular}{lc}
\hline \multicolumn{1}{c}{ Item } & String Box SB-1E/2E-1S-1000V \\
\hline Max. DC Output Voltage (Un) & $1000 \mathrm{~V}$ DC \\
Max. DC Output Current & $25^{\mathrm{a}}$ \\
DC Disconnection Type & Switch-disconnectors \\
Rated Impulse Withstand Voltage (Uimp) & $8 \mathrm{kV}$ \\
Number of DC Inputs & $1 / 2$ \\
Number of DC Outputs & 1 \\
\hline
\end{tabular}

Source: Proauto (2019). Adapted by the authors.

The economic analyses will be developed through the discounted payback method, being payback a tool for the study of the investment, to determine the time needed to restore the invested capital. Discounted payback converts cash flow amounts into present value through discount rates (Colpo, Medeiros, \& Weise, 2015).

The first step for the composition of the cash flow of each project was to estimate the avoided cost, through the potential for generation of the system, considering the power of the modules and the average daily irradiation. After calculating the loss of the system, due to the decrease in panel efficiency over the years, based on the data presented by the manufacturer, a loss of $0.80 \%$ per year was admitted (BYD, 2018).

Then, the electric energy generation potential was multiplied by the $\mathrm{kWh}$ cost, referring to each State, to obtain the avoided cost of the project. For the calculation, it was estimated the increase of the national electric energy tariffs, according to the average variation of the last 10 years, made available by the National Electrical Energy Agency - ANEEL; thus, a rate of $6.96 \%$ per year was fixed (ANEEL, 2016, 2019).

In the composition of the cash flows, the initial investment for the acquisition of the system was also taken into consideration, through the financing of $100 \%$ of the project, at 60 months, with the payments considered for the end of the study once a year, totaling 5 annual payments. The established rate was $10.70 \%$ per year, determined by the simulation available on the Banco de Desenvolvimento Nacional - BNDS website (BNDS, 2019). We also considered the cost of replacing the inverters every 10 years.

As part of the implementation expenses, an amount of $10 \%$ of the total equipment cost was considered, destined to labor, $15 \%$ of the equipment cost for the fixation structure and accessories of the system, $20 \%$ of the system design. It was also considered the freight value of the equipment for each of the regions of interest. For the calculation, it was used the simulator of the Minha Casa Solar site (2019), considering Federal Express Brazil - FedEx as the company responsible for transportation, which serves all the cities under study.

Based on the data of expenses and annual revenues obtained by the project, it was possible to calculate the annual balance of the project, subtracting the revenues from expenses, then update these balances net present values - VPL and thus verify the time of return on each investment, by means of the balance accumulated over the years. Equation 6 was used to calculate the VPL.

$$
P=\frac{F}{\left[\left(1+\mathrm{i}_{1}\right)\left(1+\mathrm{i}_{\underline{n}}\right)\right]^{\mathrm{n}}}
$$


Where:

$\mathrm{P}=$ Present value;

$\mathrm{F}=$ Future value;

i1 = Selic annual rate;

i2 = Inflation annual rate;

$\mathrm{n}=$ Number of periods.

The present value was calculated based on Selic rates and inflation, based on data from the last 12 months (September 2018 to August 2019). The Selic rate used was 6.09\% (BRASIL, 2019) and inflation was 3.38\% (IBGE, 2019).

\section{Results and Discussion}

The annual average solar irradiation data in the local horizontal plane, for the cities selected in the study, are presented in Table 6.

Table 6. Daily average annual solar irradiation in the inclined plane

\begin{tabular}{cc}
\hline City & Radiation $\left(\mathbf{k W h} \cdot \mathbf{m}^{-\mathbf{2} . d a y}\right)$ \\
\hline Manaus & 4.42 \\
Salvador & 5.40 \\
Goiânia & 5.45 \\
São Paulo & 4.64 \\
Curitiba & 4.39 \\
Cascavel & 4.94 \\
\hline
\end{tabular}

Source: CRESESB (2018). Adapted by the authors.

The unit price of each solar module is U\$ 144.55. In each of the dimensioned systems will be used two inverters and two strings-boxes, with unitary price, respectively, of U\$ 680.04 and U\$ 176.38.

Table 7 presents the data on the photovoltaic power of the system, the number of modules needed to meet the projected demand, as well as the annual potential for power generation.

The values for each of the components for system deployment are presented in Table 8 .

Table 7. Characteristics of the designed system.

\begin{tabular}{cccc}
\hline City & Power $(\mathbf{k W p})$ & Number of modules & Annual Generation (kWh) \\
\hline Manaus & 3.77 & 12 & 4,476 \\
Salvador & 3.09 & 10 & 4,551 \\
Goiânia & 3.06 & 10 & 4,594 \\
São Paulo & 3.59 & 11 & 4,298 \\
Curitiba & 3.80 & 12 & 4,434 \\
Cascavel & 3.38 & 10 & 4,161 \\
\hline
\end{tabular}


Table 8. System deployment costs (U\$ dollars).

\begin{tabular}{ccccccc}
\hline City & Equipment & Labor Supply & Fixation Structure & Engineering Project & Road Freight & Total \\
\hline Manaus & $3,447.46$ & 344.75 & 517.12 & 689.49 & 327.24 & $\mathbf{5 , 3 2 6 . 0 6}$ \\
Salvador & $3,158.35$ & 315.84 & 473.75 & 631.67 & 103.35 & $\mathbf{4 , 6 8 2 . 9 7}$ \\
Goiânia & $3,158.35$ & 315.84 & 473.75 & 631.67 & 107.37 & $\mathbf{4 , 6 8 6 . 9 8}$ \\
São Paulo & $3,302.91$ & 330.29 & 495.44 & 660.58 & 109.50 & $\mathbf{4 , 8 9 8 . 7 2}$ \\
Curitiba & $3,447.46$ & 344.75 & 517.12 & 689.49 & 107.07 & $\mathbf{5 , 1 0 5 . 8 8}$ \\
Cascavel & $3,158.35$ & 315.84 & 473.75 & 631.67 & 142.02 & $\mathbf{4 , 7 2 1 . 6 3}$ \\
\hline
\end{tabular}

Source: Authors.

The time of return for each investment is presented in Table 9.

Table 9. Project time of return.

\begin{tabular}{cc}
\hline City & Payback Time (years) \\
\hline Manaus & 9 \\
Salvador & 12 \\
Goiânia & 12 \\
São Paulo & 14 \\
Curitiba & 15 \\
Cascavel & 14 \\
\hline
\end{tabular}

Source: Authors.

It can be seen from the analysis of the performed dimensioning that the photovoltaic systems present a lot of similarity among themselves, however, when considering the economic feasibility, such projects present different times return on investment. It is observed that one of the factors that presented great influence was the cost of electric energy in each location, due to the supply being made by different electricity concessionaires.

The shortest time of return presented from the analyses was for the capital Manaus - AM, with 9 years, and the largest was Curitiba - PR with 15 years. The result for Manaus is explained by the fact that the cost of electricity is the highest among the cities studied, being U\$ 0.17 per kWh, corroborating for a higher avoided cost of the project. For the city of Curitiba, in addition to the lower cost of electricity, U\$ 0.12 per $\mathrm{kWh}$, it also has the lowest average annual irradiation, being $4.39 \mathrm{kWh} . \mathrm{m}^{-}$ ${ }^{2}$. day $^{-1}$.

Figure 3 shows the relationship between the number of panels composing the system and the annual generation of electricity. 
Figure 3. List of photovoltaic modules versus annual electricity generation.

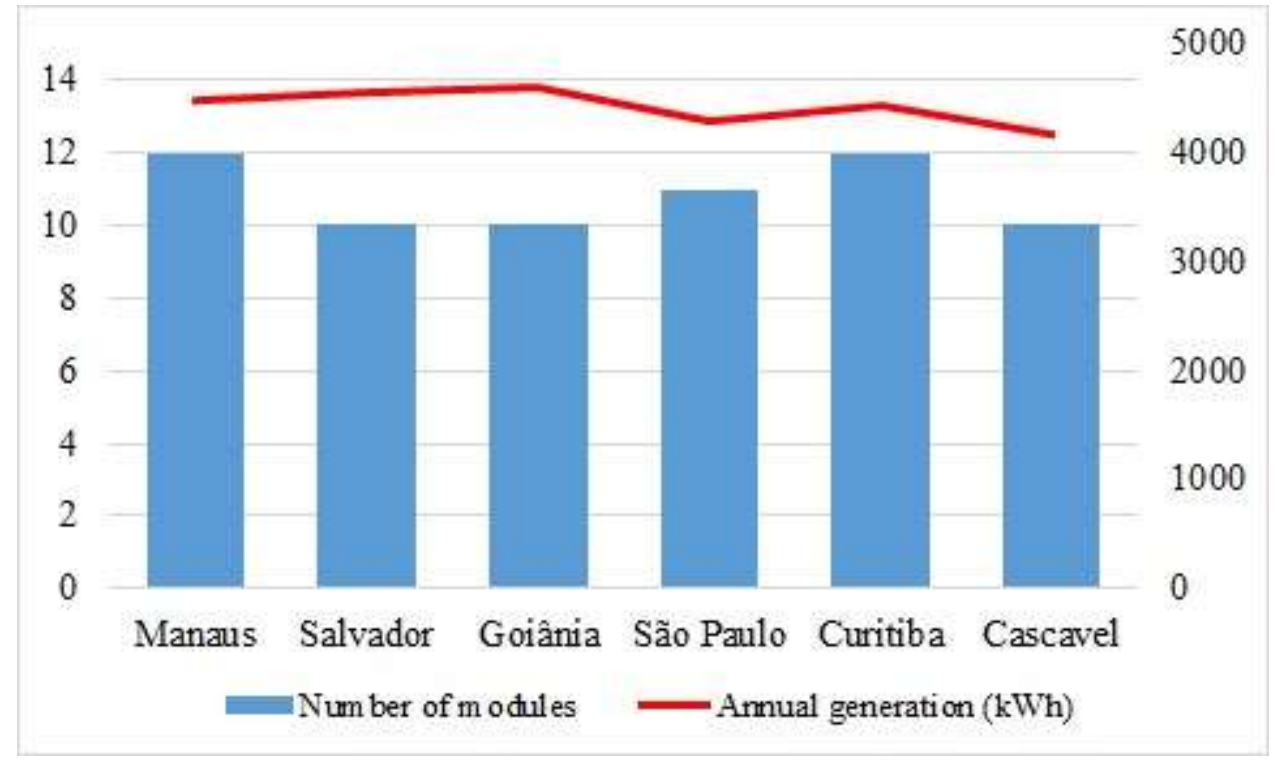

Source: Authors.

It is observed, as previously explained, that the city of Curitiba - PR is the one with the lowest ratio between them. Also, Goiânia-GO and Salvador-BA, despite having the lowest number of installed modules, generate a greater amount of energy due to their higher daily solar radiation.

It can also be verified that Manaus, despite having a higher solar radiation only than Curitiba, has the shortest return time, due to the established value of $\mathrm{kWh}$ by the regional concessionaire.

\section{Conclusions}

The investments to be made for the implementation of the dimensioned systems varied between U\$ 4,682.97 and U\$ 5,326.06; the variation between the lowest value and the highest value of the investment represents $13.73 \%$. This occurred because, despite being in such distinct regions, they were dimensioned for a fixed consumption, resulting in very similar projects.

On the other hand, the times return on investment varied between 9 and 15 years, with a variation of the highest value in relation to the lowest value of $66.67 \%$. Several factors are related to this variation; however, we can highlight the solar irradiation available in the locality and the energy tariffs, and these characteristics affect the avoided cost of the system, consequently, the time of return.

Although the projects present similar compositions and little variation in their initial investment, when we analyze the times return on investments, these present significantly different values. So, we conclude that the characteristics inherent to each region of Brazil have little effect on the dimensioning of the systems but have great influence on the annual energy generation and the time of return on investments in similar projects of photovoltaic microgeneration.

\section{References}

Alves, D. L. (2016). Geração Solar: Conceitos básicos. https://docente.ifrn.edu.br/dennysalves/disciplinas/energia-solarfv/apostila_geracao_solar_fv_0.9.1

ANEEL. (2012). Resolução Normativa $N^{\circ}$ 482, de 2012 da ANEEL. Estabelece as condições gerais para o acesso de microgeração e minigeração distribuída aos sistemas de distribuição de energia elétrica, o sistema de compensação de energia elétrica, e dá outras providências. http://www2.aneel.gov.br/cedoc/bren2012482.pdf 
ANEEL. (2015). Resolução Normativa No 687 de 2015 da ANEEL. Altera a Resolução Normativa $n^{o} 482$, de 17 de abril de 2012 , e os Módulos 1 e 3 dos Procedimentos de Distribuição - PRODIST. http://www2.aneel.gov.br/cedoc/ren2015687.pdf

ANEEL. (2016). Tensões Nominais de Tarifas. http://www.aneel.gov.br/tensoes-nominais

ANEEL. (2018). Geração Distribuída. http://www.aneel.gov.br/conteudo-educativo/-/asset_publisher/vE6ahPFxsWHt/content/geracao-distribuida-introduc$1 / 656827$ ? inheritRedirect=false

ANEEL. (2019). Relatório de Evolução das Tarifas Residenciais. http://www.aneel.gov.br/relatorio-evolucao-tarifas-residenciais

Balfour, J., Shaw, M., \& Nash, N. B. (2016). Introdução ao Projeto de Sistemas Fotovoltaicos. Rio de Janeiro, RJ: LTC.

Bhatia, S. (2014). Solar radiations (pp. 32-67). In Bhatia, S. (Ed.), Advanced renewable energy systems: Woodhead Publishing India.

BNDS. (2019). Simule o seu financiamento. https://www.bndes.gov.br/wps/portal/site/home/financiamento/simulador/?productCode=AOI

$055 \&$ valorBem $=25000 \&$ percentualFinanciado $=100 \&$ prazoFinanciamento $=90 \&$ prazoCarencia $=6 \&$ spreadAgente $=3 \&$ projecao Inflacao Anual $=3.63$

BP. (2018). Statistical Review of World Energy - all data, 1965-2018. Recuperado de https://www.bp.com/en/global/corporate/energy-economics/statisticalreview-ofworld-energy.html

BRASIL. (2019). Ministério da Economia - Receita Federal. Taxa de Juros Selic Acumulada Mensalmente.

http://receita.economia.gov.br/orientacao/tributaria/pagamentos-e-parcelamentos/taxa-de-juros-selic\#Selicmensalmente

BYD. (2018). Modulo Fotovoltaico BYD PHK-36-SÉRIE-4BB. https://recursos.minhacasasolar.com.br/MediaCenter/Datasheet-Painel-Solar-BYD-330W.pdf

Cirilo, J. A. (2015). Crise hídrica: desafios e superação. Revista USP, 106, 45-58, 2015.

Chamma, B. C. (2017). Projeto de uma microgeração fotovoltaica aplicada a uma residência (Trabalho de Conclusão de Curso). Universidade Federal do Rio de Janeiro, Rio de Janeiro, Brasil.

Colpo, I., Medeiros, F. S. B., \& Weise, A. D. (2015). Retorno do investimento: o caso de uma microempresa com produção sazonal. In III Simpósio de Engenharia de Produção, João Pessoa, PB.

CRESESB. (2018). Base de Dados de radiação solar incidente (irradiação solar). http://www.cresesb.cepel.br/index.php?section=sundata\&

Ecosolys. (2017). Inversor Grid-Tie Ecosolys ECOS2000 PLUS. https://recursos.minhacasasolar.com.br/MediaCenter/Datasheet-Inversor-Solar-Ecos-200Plus-Ecos-3000.pdf

EPE. (2018). Consumo Mensal de Energia Elétrica por Classe (regiões e subsistemas). Recuperado de http://epe.gov.br/pt/publicacoes-dadosabertos/publicacoes/Consumo-mensal-de-energia-eletrica-por-classe-regioes-e-subsistemas

EPE. (2019). Balanço Energético Nacional 2019: Relatório síntese (Ano base 2018). http://www.epe.gov.br/sites-pt/publicacoes-dadosabertos/publicacoes/PublicacoesArquivos/publicacao-377/topico-470/Relat\%C3\%B3rio\%20S\%C3\%ADntese\%20BEN\%202019\%20Ano\%20Base\%2020 18.pdf

França, E. A. C., Vinagre, M. V. A., Fonseca, N. D. L. V., Lopes, M. S. B., Ponte, M. J. M., \& Lima, A. C. M. (2021). Uso da geração fotovoltaica para viabilização de projetos de Mecanismo de Desenvolvimento Limpo. Research, Society and Development, $10(12)$, e583101220731.

IBGE. (2018). Características Geral dos Domicílios e dos Moradores. https://www.ibge.gov.br/estatisticas/sociais/populacao/9171-pesquisa-nacional-poramostra-de-domicilios-continua-mensal.html?=\&t=downloads

IBGE. (2019). Índice Nacional de Preços ao Consumidor Amplo - IPCA. https://www.ibge.gov.br/estatisticas/economicas/precos-e-custos/9256-indicenacional-de-precos-ao-consumidor-amplo.html?=\&t=o-que-e

Global Solar Atlas. (2019). Mapas e dados. https://globalsolaratlas.info/

Goh, C. S. (2019). Energy: Current Approach. In Tam, V. W. Y., Le, K. N. (Ed.), Sustainable Construction Technologies (Cap. 6, pp. 145-149). Amsterdam: Butterworth-Heinemann.

Guney, M. S. (2016). Solar Power and application methods. Renewable and Sustainable Energy Reviews, 57, 776-785, 2016.

Kalogirou, S. A. (2014). Environmental Characteristics. In Kalogirou, S. A. (Ed.), Solar Energy Engineering: Processes and Systems. Boston: Academic Press.

Lacchini, C. (2017). Análise econômica de sistemas fotovoltaicos residenciais no contexto brasileiro, com foco nos indicadores financeiros e nas Tarifas locais de energia elétrica (Tese de Doutorado). Universidade Federal de Santa Catarina, Florianópolis, Brasil.

Maimoni, F. P., \& Cardoso, R. B. (2020). Análise de viabilidades econômicas para alternativas de utilização da energia solar em residências do Estado de Minas Gerais, Brasil. Research, Society and Development, 9(8), e853986221.

Minha Casa Solar. (2019). Site de vendas equipamentos fotovoltaicos. https://www.minhacasasolar.com.br/

Mitscher, M., \& Rüther, R. (2012). Economic performance and policies for grid-connected residential solar photovoltaic systems in Brazil. Energy Policy, 49, 688-694. 
Research, Society and Development, v. 10, n. 17, e179101724557, 2021

(CC BY 4.0) | ISSN 2525-3409 | DOI: http://dx.doi.org/10.33448/rsd-v10i17.24557

Mundo-Hernández, J. J., Alonso, B. C., Hernández-Álvarez, J., \& Celis, B. (2014). An overview of solar photovoltaic energy in Mexico and Germany. Renewable and Sustainable Energy Reviews, 31, 639-649.

Nascimento, L. F. J. (2018). Desempenho de um sistema de irrigação por gotejamento com sistema fotovoltaico amorfo para bombeamento de água (Dissertação de Mestrado). Universidade Estadual do Oeste do Paraná, Cascavel, Brasil.

Nakabayashi, R. K. (2014). Microgeração fotovoltaica no Brasil: condições atuais e perspectivas futuras (Dissertação de Mestrado). Universidade de São Paulo, São Paulo, Brasil.

Pazuch, F. A. (2017). Desenvolvimento de uma ferramenta computacional para o dimensionamento de sistemas fotovoltaicos isolados e interligados à rede (Dissertação de Mestrado). Universidade Estadual do Oeste do Paraná, Cascavel, Brasil.

Pereira, E. B., Martins, F. R., Gonçalves, A. R., Costa, R. S., Lima, F. L., Rüther, R. ... Souza, J. G. (2017). Atlas brasileiro de energia solar. 2.ed. São José dos Campos, SP: INPE.

Pinho, J. T., \& Galdino, M. A. (2014). Manual de Engenharia para Sistemas Fotovoltaicos. Rio de Janeiro, RJ: Cepel-Cresesb.

Proauto. (2019). String Box SB-1E/2E-1S-1000V. https://recursos.minhacasasolar.com.br/MediaCenter/Datasheet-StringBox-Proauto-2E-1S.pdf

Silveira, V. F., Siqueira, J. A. C., Nascimento, L. F. J., Tokura, L. K., Alovisi, A. M. T., Vilas Boas, M. A. ... Debastiani, G. (2021). Comparative study of drip irrigation systems using indoor amorphous photovoltaic panels. Research, Society and Development, 10(11), e125101119288.

Vargas, M. C., Siqueira, J. A. C., Tokura, L. K., Santos, R. F., \& Feiber, F. N. (2021). Solar energy available and energy generated in photovoltaic systems in different inclinations and orientations of roofs of buildings. Research, Society and Development, 10(16), e279101623494.

Villalva, M. G. (2015). Energia solar fotovoltaica: conceitos e aplicações.( 2. ed. rev. e atual.) São Paulo, SP: Érica.

Xu, B., Wang, G., Zhou, Y., Li, Q., \& Xu, Q. (2018). Improving the photovoltaic effect by resistive switching. Applied Physics Letter. $113,133901$.

Wen Y., \& Zhou J. (2019). Metamaterial route to direct photoelectric conversion. Materials Today, 23, 37-44. 